\title{
Explicit terror prevention versus vague civil liberty: How the UK broadcasting news (de)legitimatise online mass surveillance since Edward Snowden's revelations
}

\author{
Lischka, Juliane A
}

\begin{abstract}
Snowden's initial revelations aimed at establishing a public debate on online surveillance informed through the media. Media should serve the public's need for information and offer various viewpoints and sources to enhance public debates. This study assesses how online surveillance is justified or countered in British broadcast news since the 2013 Snowden revelations for five selected major events in news coverage ending with the Charlie Hebdo aftermath in Paris in early 2015. The critical discourse analysis shows that UK broadcasts cover justification and delegitimation arguments of online surveillance. Online surveillance legitimation combines rationalisation (terror prevention) and moral evaluation (public security) arguments, which are often expressed by governmental actors. The broadcast discourse tends to give governmental, pro-surveillance actors a voice by default. The detailedness of terror threat descriptions increases over time. In 2013, 'terrorist attacks' are rather factually mentioned. In 2015, several ways leading to a loss of lives through terror are explicitly stated, which strengthens the instrumental rationality legitimation arguments. Delegitimising arguments predominantly use moralising and mythopoetic arguments (civil liberties) that are expressed by Snowden himself or politicians, yet rarely by non-governmental organisations, and very rarely by citizens. It is harder for non-governmental actors to continuously interpret the broadcast discourse. Therefore, what exactly is at stake when online mass surveillance increases remains obscure in the news discourse. The surveillance discourse should be richer in order to give the audience a chance to understand the vague and less tangible contra-surveillance arguments better.
\end{abstract}

DOI: https://doi.org/10.1080/1369118X.2016.1211721

Posted at the Zurich Open Repository and Archive, University of Zurich

ZORA URL: https://doi.org/10.5167/uzh-125063

Journal Article

Accepted Version

Originally published at:

Lischka, Juliane A (2017). Explicit terror prevention versus vague civil liberty: How the UK broadcasting news (de)legitimatise online mass surveillance since Edward Snowden's revelations. Information, Communication and Society, 20(5):665-682.

DOI: https://doi.org/10.1080/1369118X.2016.1211721 


\section{Explicit Terror Prevention Versus Vague Civil Liberty}

\section{How the UK Broadcasting News (De)Legitimatise Online Mass Surveillance since Edward \\ Snowden's Revelations}

Author: Juliane A. Lischka

Affiliation: Institute of Mass Communication and Media Research, University of Zurich, Andreasstrasse 15, 8050 Zurich, Switzerland

Contact details: j.lischka@ipmz.uzh.ch, Tel: +41 (0)44 6352075

Word count: 7929 (excluding abstract)

Abstract: Snowden's initial revelations aimed at establishing a public debate on online surveillance informed through the media. Media should serve the public's need for information and offer various viewpoints and sources to enhance public debates. This study assesses how online surveillance is justified or countered in British broadcast news since the 2013 Snowden revelations for five selected major events in news coverage ending with the Charlie Hebdo aftermath in Paris in early 2015. The critical discourse analysis shows that UK broadcasts cover justification and delegitimation arguments of online surveillance. Online surveillance legitimation combines rationalisation (terror prevention) and moral evaluation (public security) arguments, which are often expressed by governmental actors. The broadcast discourse tends to give governmental, pro- 
Published as: Lischka, J. A. (2016). Explicit terror prevention versus vague civil liberty: How the UK broadcasting news (de)legitimatise online mass surveillance since Edward Snowden's revelations. Information, Communication \& Society. doi:10.1080/1369118X.2016.1211721

surveillance actors a voice by default. The detailedness of terror threat descriptions increases over time. In 2013, 'terrorist attacks' are rather factually mentioned. In 2015, several ways leading to a loss of lives through terror are explicitly stated, which strengthens the instrumental rationality legitimation arguments. Delegitimising arguments predominantly use moralising and mythopoetic arguments (civil liberties) that are expressed by Snowden himself or politicians, yet rarely by non-governmental organisations, and very rarely by citizens. It is harder for non-governmental actors to continuously interpret the broadcast discourse. Therefore, what exactly is at stake when online mass surveillance increases remains obscure in the news discourse. The surveillance discourse should be richer in order to give the audience a chance to understand the vague and less tangible contra-surveillance arguments better.

Key words: Surveillance, Privacy, Internet, News, Terrorism, Data Protection

\section{Introduction}

With the Internet and advanced technologies, people experience an increase of online and offline mass surveillance and a reduction of privacy. Since the $9 / 11$ attacks in the US, the 7/7 attacks in the UK, and more recently since Snowden's revelations, media attention toward surveillance practices and technologies has increased in the UK as well as globally (Barnard-Wills, 2011). Since journalistic language may be related to power or ideologies and is described to exert power to the audience (Branum \& Charteris-Black, 
Published as: Lischka, J. A. (2016). Explicit terror prevention versus vague civil liberty: How the UK broadcasting news (de)legitimatise online mass surveillance since Edward Snowden's revelations. Information, Communication \& Society. doi:10.1080/1369118X.2016.1211721

2015; Richardson, 2007) in an age of growing mediatization (Christensen \& Jansson, 2015), it is important to assess how online surveillance is discussed and justified or countered in the news media. In his normative theory of media and society, McQuail (2005, p. 170) argues that media has to conduct in a public interest, 'being a vehicle for advancing freedom and democracy' and 'serving the public's need for information and comment and providing the platforms for expression of diverse ideas.' Lyon (2002, p. 251) requests that 'some social practices and technological systems that affect everyone [...] [need to be] understood and actively negotiated by everyone.' Citizens must be able to understand what is at stake with mass surveillance to 'stand up for their freedom' (Gürses, Kundnani, \& van Hoboken, 2016, p. 582). An adequate media coverage would establish online surveillance as a salient issue enabling and enhancing a public debate about surveillance, which was Snowden's initial intention to become a whistle blower (Guardian US, 2013). So, how well did the media do?

Generally speaking, media discourses occur within wider processes of social and cultural change, power relations and ideological societal processes (Fairclough, 1995). Different actors and content compete for interpretative dominance of the media discourse. Government discourses may strive to 'discipline the citizenry' (Simone, 2009, p. 12) and the media takes up politicians' arguments, among others, to build up its agenda (van Leeuwen \& Wodak, 1999, p. 111). Broadcast news reports to a lay public audience according to specific news making principles and processes, which may differentiate 
Published as: Lischka, J. A. (2016). Explicit terror prevention versus vague civil liberty: How the UK broadcasting news (de)legitimatise online mass surveillance since Edward Snowden's revelations. Information, Communication \& Society. doi:10.1080/1369118X.2016.1211721

across news outlets, e.g., depending on economic constraints or editorial stance (see e.g. Sup Park, 2014). Previous research has not analysed the broadcasting surveillance discourse, although it is a major information source of the public. The goal of the present analysis is to trace the British broadcast news debates on online surveillance. We decode discursive formation about online surveillance in broadcast news using critical discourse analysis of the broadcast 'data' to reveal how online surveillance was represented and (de)legitimised according to van Leeuwen and Wodak's (1999) legitimation strategies.

This study analyses the online surveillance discourse in British broadcast news for five selected events, i.e., (1) the Snowden revelations in June 2013, (2) the snooping on embassies and world leaders, (3) the detention of David Miranda, (4) the report into the death of Lee Rigby, and ending with (5) the Charlie Hebdo aftermath in January and February 2015. The research questions are as follows.

RQ 1. How is online surveillance (de)legitimised in the broadcast news debate through major events of Snowden's unveiling, the David Miranda detention, the snooping on embassies and world leaders, the Lee Rigby report, and the Charlie Hebdo aftermath?

RQ 2. What actors and sources articulate opinions on online surveillance and to what extend are citizens' voices included in the broadcast news debate? 
Published as: Lischka, J. A. (2016). Explicit terror prevention versus vague civil liberty: How the UK broadcasting news (de)legitimatise online mass surveillance since Edward Snowden's revelations. Information, Communication \& Society. doi:10.1080/1369118X.2016.1211721

\section{Literature Review}

\section{Surveillance, Privacy, and the State}

Surveillance is described as means to secure the existence of a state and the security of its citizens. Lyon (2004, p. 135) defines surveillance as 'the rationalised control of information within modern organisations, and involves in particular processing personal data for the purposes of influence, management, or control', globally catalysed by the terrorist attacks of 9/11. One development in the UK is the extensive CCTV surveillance, making Britain 'the clear world leader in CCTV deployment' (Lyon, 2004, p. 142). In the digital age, citizens as well as organisations leave manifold footprints online. As a result, 'We are experiencing a reduction in privacy, changes in norms of communicative behaviour, and unparalleled surveillance by commercial firms and governments alike' (Picard, 2015, p. 37).

Surveillance legislation is typically framed as counter-terrorism laws (MacDonald \& Hunter, 2013; MacDonald, Hunter, \& O'Regan, 2013; McGarrity, 2011). The reason for a need of online surveillance lays in the state's purpose 'to ensure the wellbeing of the population, expressed in its longevity, health and wealth' (MacDonald \& Hunter, 2013, p. 124). Surveillance is one means of security, which constitutes one form of state power besides feudal sovereignty and individually restrictive discipline (i.e., through sentencing criminal acts) (Foucault, 2007). Picard (2015) draws parallels to Platonic, Machiavellian, and Lockean arguments supporting governmental surveillance, because the state must 
Published as: Lischka, J. A. (2016). Explicit terror prevention versus vague civil liberty: How the UK broadcasting news (de)legitimatise online mass surveillance since Edward Snowden's revelations. Information, Communication \& Society. doi:10.1080/1369118X.2016.1211721

protect its population. Especially when the existence of the state is threatened, 'ordinary morality does not apply' (Picard, 2015, p. 37) and 'unlimited surveillance is the unspoken goal (and it is attractive to politicians, police, marketers and high-tech companies alike)' (Lyon, 1998, p. 101). Consequently, 'the all-seeing state [...] no longer respects freedom' of citizens (Gürses et al., 2016, p. 580).

Counter-terrorism and preventing violent extremism discourses have appeared more intensely after the $7 / 7$ attacks on the London transport system, expressed through keywords such as security, extremism or terrorism (MacDonald et al., 2013). MacDonald and Hunter (2013) conclude from an analysis of UK counter-terrorism policy documents between 2007 and 2011 that the issue of national security remains a central concern in the background of the $7 / 7$ attacks. Simone $(2009$, p. 1) shows that the US government discourse of surveillance emphasises the 'government as protector, the American citizen as innocent and terrorists as a foreign menace' in order to legitimise the USA PATRIOT Act. More specifically, the argumentation follows four premises.

'(1) Security is necessary for liberty.

(2) Terrorists have threatened US and global security.

(3) The USA PATRIOT Act improves security.

(4) Thus, the Act, as the symbol for security, enhances liberty.'

(Simone, 2009, p. 5)

For explaining surveillance legitimation expressed by the German government in the background of the 'NSA-surveillance scandal' in 2013, Schulze (2015, p. 199) refers to Max Weber's typology of authority structures, 'either by relying on tradition and norms 
Published as: Lischka, J. A. (2016). Explicit terror prevention versus vague civil liberty: How the UK broadcasting news (de)legitimatise online mass surveillance since Edward Snowden's revelations. Information, Communication \& Society. doi:10.1080/1369118X.2016.1211721

('because it was always done like this'), authority or charismatic leadership ('because I say so') or by giving rational-legal reasons ('because it is the most effective way to do this' or 'because it is the law'),' whereas the latter is said to be most common in democratic societies. Surveillance was legitimised through the security of the population and soldiers as well as through the threat of terrorism. The authority of the law was especially used by the German conservative party to legitimise surveillance, whereas the opposition questioned inconsistent statements of the government and tried to broaden the debate (Schulze, 2015, p. 211).

However, the state risks its democratic existence through overstraining privacy through mass surveillance. Abu-Laban and Bakan (2012) argue that state interventions framed to protect the public against terrorism jeopardise the freedom of speech or freedom of assembly. Stoycheff (2016) explores how mass surveillance may silence democratic discourse through self-censorship of citizens. The Committee of Ministers of the Council of Europe (2005) has highlighted that free and unhindered information is most effective for helping to prevent terrorism:

'in their fight against terrorism, states must take care not to adopt measures that are contrary to human rights and fundamental freedoms, including the freedom of expression, which is one of the very pillars of the democratic societies that terrorists seek to destroy'

In this regard, Coll (2014, p. 1261) argues that privacy should also protect the society and its democratic values besides protecting individuals. Sloan and Warner (2015) warn that the massive governmental capacity of knowledge reduces privacy in public and thus risks 
Published as: Lischka, J. A. (2016). Explicit terror prevention versus vague civil liberty: How the UK broadcasting news (de)legitimatise online mass surveillance since Edward Snowden's revelations. Information, Communication \& Society. doi:10.1080/1369118X.2016.1211721

people's ability to adequately manage private information. Normally, people would willingly limit and control their knowledge of each other when they interact based on norms. In times of surveillance, 'Governmental surveillance can, and does, undermine the norm-based coordination on which privacy in public depends' (Sloan \& Warner, 2015 , p. 3). Hence, 'the erosion of privacy can threaten our autonomy, not merely as consumers but as citizens' (Acquisti, Brandimarte, \& Loewenstein, 2015, p. 509).

Gangadharan (2015, p. 12) concludes from a field study on US citizens that "people "on the wrong side of the digital divide" did not have the luxury of letting privacy or surveillance concerns dictate choices about how to adopt and interact with digital technologies.' The state is thus requested to adapt legislation to protect 'real peoplewho are naïve, uncertain, and vulnerable' and restore 'the balance of power between those holding the data and those who are the subjects of that data' (Acquisti et al., 2015, p. 514). However, 'Although it is recognized - even within security agencies - that carrying out these [surveillance] activities [...] pose risks to democracy [...] the public through acquiescence in pursuit of a perception of security - find them useful' (Picard, 2015, p. 37). Hence, civil security may win over civil liberty. Yet a moderate as opposed to an all-seeing state would not ignore the question of adequacy and proportionality of terrorism-related surveillance legislation. 
Published as: Lischka, J. A. (2016). Explicit terror prevention versus vague civil liberty: How the UK broadcasting news (de)legitimatise online mass surveillance since Edward Snowden's revelations. Information, Communication \& Society. doi:10.1080/1369118X.2016.1211721

\section{Surveillance Discourses in the Media}

In a normative view, the media is regarded as fourth estate fulfilling tasks for democracy through informing citizens and shaping public discourse. According to the Habermasian (1989) ideal of a discursive public sphere, the media discourse should enable rational discussions. Concerning reporting on surveillance legislation, McGarrity (2011, p. 274) normatively expects the media to publish leaked information and to force 'agencies to explain their actions, and thereby enables an intelligent and cool-headed assessment of whether these are proportionate to the threat of terrorism.' However, access to information on national security matters is limited and thus media cannot effectively perform its watchdog role (McGarrity, 2011, p. 280). As a result, media performance is criticised and the media rather function as government lapdog (McGarrity, 2011), resulting in an agenda silencing and a poor surveillance discourse (Greenberg \& Hier, 2009; Herfroy-Mischler, 2015). Herfroy-Mischler (2015, p. 244) requests media to 'communicate and legitimize silences orchestrated by security and intelligence censorship.'

Barnard-Wills (2011) shows that the surveillance discourse in UK newspapers ranges from preventing criminality to limiting personal liberty. Branum and CharterisBlack (2015) analyse the reporting strategies on the Snowden affair of three major UK newspapers revealing that news are biased according to the newspaper's ideology, news values, and audience considerations. In the Guardian, being a key newspaper publishing 
Published as: Lischka, J. A. (2016). Explicit terror prevention versus vague civil liberty: How the UK broadcasting news (de)legitimatise online mass surveillance since Edward Snowden's revelations. Information, Communication \& Society. doi:10.1080/1369118X.2016.1211721

Snowden's leaks in the first place, surveillance is described as insidious and extensive.

The Guardian uses legal, moral, and public-support arguments to justify reporting. The Daily Mail reports refer to Snowden's living situation and personal life and remain neutral and propositional (Branum \& Charteris-Black, 2015, p. 210). The Sun's reporting defends surveillance through emphasising the damage caused by the leaks and criticises the Guardian's reports. Thus, the Sun's reports reflect protection-of-the-state arguments to legitimise surveillance whereas the Guardian focuses on the risks for democracy and unlawfulness.

In a linguistic analysis of surveillance discourse themes in UK broadsheets in the period of 2001 to 2005, Wiegand (2015) reveals that 'othering' is an often used theme, i.e., describing the union of America and Britain ('us') versus bin Laden and terrorism ('them'), which is also found in an analysis of policy documents on UK counter-terrorism (MacDonald \& Hunter, 2013).

In sum, previous research suggests that the media discourse on surveillance is shaped by governmental actors and their legitimation strategies and depends on intelligence services' censorship. The British 'ideologically polarized press' (Brüggemann, Engesser, Büchel, Humprecht, \& Castro, 2014, p. 1043) often adopts the security and terrorism reasoning according to their editorial stance (Branum \& CharterisBlack, 2015). In addition to the press, the public-service broadcaster (PSB) BBC is a popular information source for publicly relevant issues having a 'powerful effect [...] on 
Published as: Lischka, J. A. (2016). Explicit terror prevention versus vague civil liberty: How the UK broadcasting news (de)legitimatise online mass surveillance since Edward Snowden's revelations. Information, Communication \& Society. doi:10.1080/1369118X.2016.1211721

the political knowledge of the citizenry' (Brüggemann et al., 2014, p. 1058). Thus, we expect that government views legitimising surveillance are a major part of broadcast reporting varying according to a broadcaster's stance. However, the BBC with its value of impartial, objective, and balanced reporting should take up a greater variety of viewpoints.

\section{Method}

\section{Sample}

Broadcasts were identified using search terms from two data bases, the Television and Radio Index for Learning and Teaching (TRILT) as well as Box of Broadcasts (BoB). The sample frame contains broadcasts of more than 475 TV and radio channels including all BBC TV and radio content. The sampling procedure encompasses two steps. First, to gain an overview over reports on online surveillance and intelligence services, the broadcast data bases were searched by the terms 'Edward Snowden,' 'GCHQ' or 'NSA' for a two-year period from 27/06/2013 until 28/06/2015. From this search, five major events in relation to the Snowden revelations and surveillance could be identified.

The observation period begins three days after the initial revelations with Snowden's unveiling as the source of the leaks on 9. June 2013 and includes four further major events that were discussed in relation to surveillance. The events include (1) Snowden's unveiling, (2) the detention of journalist Glen Greenwald's partner David 
Published as: Lischka, J. A. (2016). Explicit terror prevention versus vague civil liberty: How the UK broadcasting news (de)legitimatise online mass surveillance since Edward Snowden's revelations. Information, Communication \& Society. doi:10.1080/1369118X.2016.1211721

Miranda at Heathrow Airport under anti-terror legislation, (3) the interception of communications in foreign embassies and European Union offices and spying on world leaders' phone communications, in particular the German Chancellor Angela Merkel, (4) the publication of the British parliamentary report into the death of Fusilier Lee Rigby that raised debates about Facebook and social media companies' role in tackling terrorism, and (5) the Charlie Hebdo terror attacks in Paris which prompted debates about digital encryption, freedom of speech, and the resurrection of the so called 'Snoopers' Charter' legislation.

Second, key search terms were developed specifically for each event to ensure that all broadcasts related to the event are found (see Table 1). Broadcasts were analysed when the recording was available, which decreased the sample slightly for the David Miranda and Lee Rigby cases. Analysis was based on the transcripts of each recording.

It is important to note that due to key word searching in short summaries and transcripts of broadcasts, TV programmes had a greater chance to be part of the sample than radio programmes due to the existence of transcripts for TV (based on their subtitles). Thus, the radio programmes that did not contain the search terms in their short summary are systematically overlooked in our sample.

Four broadcasts are found on Snowden's unveiling: (1) Sky News At 9 (09/06/13, ca. 6'30'’), (2) BBC NEWS at 10pm (09/06/13, ca. 4'), (3) BBC NEWS at 3pm (11/06/13, ca. 6'), and (4) BBC NEWS at 10pm (13/06/13, ca. 2'30''). Whereas the first three news 
Published as: Lischka, J. A. (2016). Explicit terror prevention versus vague civil liberty: How the UK broadcasting news (de)legitimatise online mass surveillance since Edward Snowden's revelations. Information, Communication \& Society. doi:10.1080/1369118X.2016.1211721

reports were the opener of each news show, the fourth news broadcast is the presented toward the end of the news show.

Twelve broadcasts are found on David Miranda, of which for eight the programme could be obtained: (1) Today, BBC Radio 4, at 7.50am (19/08/13, ca. 4'40'), (2) Today, BBC Radio 4, at 8am (19/08/13, ca. 1'), (3) BBC News at Ten, at 10pm (19/08/13, ca. 5'30'), (4) Drive, BBC Radio 5, at 4pm (20/08/13, ca. 4'30'), (5) BBC News at Six, at 6pm (20/08/13, ca. 5'10'), (6) Channel 5 News, at 9pm (20/08/13, ca. 20'”), (7) BBC News at Ten, at 10pm (20/08/13, ca. 5'30''), and (8) The Media Show, BBC Radio 4, at 4.30pm (21/08/13, ca. 11'30'’).

[Insert Table 1 about here]

Two broadcasts were found and obtained relating to the spying on EU offices: (1) BBC News, 6.35pm (30/06/2013, ca. 2'20') and (2) BBC News at Ten, 10pm (30./06/2013, ca. 2'20’'). Both reports are similar.

Eleven broadcasts were found and obtained on the snooping on world leaders: (1) Sky News At 9, 9pm (23/10/2013, ca. 2’40’’), (2) Sky News At 10, 10pm (23/10/2013, ca. 2'40'’), (3) BBC News, at 9am (24/10/2013, ca. 7'50'), (4) Sky News, at 9am (24/10/2013, ca. 3'), (5) BBC News, at 10am (24/10/2013, ca. 5'30'’), (6) BBC News, at $11 \mathrm{am}(24 / 10 / 2013$, ca. 3’30'), (7) BBC News at One, at 1pm (24/10/2013, ca. 4'50’'), (8) Breaking News, BBC NEWS, at 7.45pm (24/10/2013, ca. 3'10'”), (9) News at eight, BBC NEWS, at 8pm (24/10/2013, ca. 4'), (10) Dateline London, BBC NEWS, at 11.30am 
(26/10/2013, ca. 11'40') ), and (11) Politics Europe, BBC NEWS, at 5.30pm (24/10/2013, ca. 4'). The broadcasts of October 23rd and 24th are mostly similar in structure, content, and sources.

Eight broadcasts were detected for the Lee Rigby report, of which the transcripts for seven could be obtained: (1) Jeremy Vine on BBC Radio 2, 12.00 (25/11/2014, ca. 8'), (2) BBC News at One, at 1pm (25/11/2014, 7'), (3) Channel 4 News, at 7pm (25/11/2014, ca. 12'), (4) 5 News Update on Channel 4, at 7.55pm (25/11/2014, ca. 45') $)$, (5) 5 News Update on Channel 4, at 20.58pm (25/11/2014, ca. 10'), (6) Sky News At Ten, 10pm (25/11/2014, ca. 4'), (7) ITV News at Ten \& Weather, at 10pm (25/11/2014, ca. 7'), and (8) Today in Parliament on BBC Radio 4 (25/11/2014, ca. 7'). Broadcasts (4) and (5) very briefly summarise the event in one headline and are excluded.

One broadcast was detected on surveillance that refers to the Charlie Hebdo attacks: (1) Today in Parliament on BBC Radio 4, 11.30pm (14/01/2015).

\section{Analytic Framework}

The deconstruction of discursive formation of arguments concerning surveillance over the course of the observation period follows a framework for analysis building up on multimodal (de)legitimation strategies by van Leeuwen and Wodak (1999), van Leeuwen (2007), and van Dijk (2006). van Leeuwen and Wodak (1999) and van Leeuwen (2007) distinguish four sub-categories of justifying strategies, namely, (1) authorisation through personal or impersonal institutionalised authorities (e.g., experts, parent, teacher, 
Published as: Lischka, J. A. (2016). Explicit terror prevention versus vague civil liberty: How the UK broadcasting news (de)legitimatise online mass surveillance since Edward Snowden's revelations. Information, Communication \& Society. doi:10.1080/1369118X.2016.1211721

the law, through conformity ['everybody does it', use of statistics]), (2) instrumental or theoretical rationalisation through purposes (e.g., intrusion into privacy is justified 'to protects rights and freedom of others' (van Leeuwen \& Wodak, 1999, p. 106)), (3) moral abstractions and evaluations that link activities to values such as leadership and governmental control, economic values (economic interest of a country), values of public interest, national security or public order, and (4) mythopoesis through telling stories. Similar legitimation strategies were also used in Schulze's (2015) analysis of the surveillance discourse of German politicians. In addition, van Dijk (2006, p. 380) describes various forms of positive self-presentation and negative other-presentation through 'enhancing the power, moral superiority and credibility of the speaker(s), and discrediting dissidents, while vilifying the Others, the enemy; the use of emotional appeals; and adducing seemingly irrefutable proofs of one's beliefs and reasons'.

The primary level of analysis are the cases in order to trace how each case informs the surveillance debate and public understanding of surveillance. First, each broadcast was sequentially summarized according to actors and themes. Next, the structure of themes over all broadcasts per case was analysed and related to legitimacy and delegitimacy arguments. 
Published as: Lischka, J. A. (2016). Explicit terror prevention versus vague civil liberty: How the UK broadcasting news (de)legitimatise online mass surveillance since Edward Snowden's revelations. Information, Communication \& Society. doi:10.1080/1369118X.2016.1211721

\section{Results}

\section{Edward Snowden's Unveiling}

\section{Public Interest and Unlawfulness}

The first parts of the reports express that the revelations are in the public interest and criticise the scope ('massive,' 'huge scale') of online surveillance, yet not online surveillance itself. Snowden declares, 'I think the public is owed an explanation of the people who make the disclosure that are outside of the democratic model. When you are subverting the power of government that is a fundamentally dangerous thing to democracy ...' Journalists describe that Snowden was 'deeply bothered and concerned' and quote Snowden describing surveillance as 'grave threat to civil liberties.' These statements refer to a moral evaluation giving public interest and democracy a higher priority than security practices. Further delegitimation of online surveillance is created by ascribing authority to Snowden through positive attributions of being a celebrated hero (see Figure 1 for an overview of [de]legitimation arguments). The anchors mention that Snowden's revelations have caused 'a storm of outrage' in the US, a petition of supporters of Snowden 'hailing him a national hero,' collecting 'thousands of signatures' and that 'Mr. Snowden is celebrated' by Hong Kong newspapers.

The surveillance practices are additionally delegitimised through reference to the law. The BBC security correspondent explains that surveillance practices of NSA and 
Published as: Lischka, J. A. (2016). Explicit terror prevention versus vague civil liberty: How the UK broadcasting news (de)legitimatise online mass surveillance since Edward Snowden's revelations. Information, Communication \& Society. doi:10.1080/1369118X.2016.1211721

GCHQ could be unlawful since 'Americans to spy on Britons,' which is complemented with Snowden's description of mass surveillance practices, 'The NSA targets the communications of everyone. It ingests them by default. It filters them and analyses them and measures and stores them for periods of time.' Snowden's statement emphasises insatiability of online surveillance practices. The reports give much voice to Snowden himself for delegitimising mass surveillance, but give only once voice to a citizen mentioning in a 10-second statement examples of mass surveillance in private life, 'Your bank records, your phone conversations, your e-mail, your documents. Anything that is connected online, they are taking.' This statement as well as Snowden's description of the NSA surveillance practice indicate a large volume of surveillance.

Besides the citizen statement, the reports do not clarify what data exactly are collected by the security agencies. Thus, although the immensity of online surveillance is understandable for the audience, it remains unclear to what extent online surveillance affects each society member on a personal level.

\section{Lawfulness and Need for Security}

The initial argument of the unlawfulness of online surveillance is immediately contrasted with voices against Snowden's revelations and legitimation reasons for online surveillance. Most statements by governmental bodies are critical about Snowden and supportive of the current state of surveillance practices. Governmental actors discredit and de-authorise Snowden by referring to negative representations. An often showed 
Published as: Lischka, J. A. (2016). Explicit terror prevention versus vague civil liberty: How the UK broadcasting news (de)legitimatise online mass surveillance since Edward Snowden's revelations. Information, Communication \& Society. doi:10.1080/1369118X.2016.1211721

statement of the Foreign Secretary MP describes Snowden's accusations as 'baseless', 'fanciful', and 'nonsense'. Also the critical US president's and the director of the NSA's stances ('reckless' and 'unpatriotic, dangerous to American interest') are mentioned. A member of the Ministry of Defence emphasises that 'surveillance is necessary in cyber as in ordinary space,' it is 'within a strict legal and policy framework,' and 'we need [...] not be so worried.' These messages express that surveillance is lawful and should be trusted. This governmental actor legitimises online surveillance by referring to the law as institutionalised authority and conformity to offline surveillance ('as in ordinary space'). Mass surveillance is also justified by its ability to prevent terror, which represents an instrumental rationalization of having an important positive utility for society. A journalist reports that social online media 'also become a place to hatch terror plots' and that surveillance is 'needed to prevent terrorist attacks.' This instrumental rationalisation is related to the moral value of public security.

The unlawfulness of Snowden's revelations is associated with these legitimation strategies emphasizing the lawfulness of surveillance. Snowden's disappearance in Hong Kong is associated to the legal consequences for Snowden facing 'decades in jail.' Snowden is quoted stating 'You cannot come up against these intelligence agencies and be free from risk, because they are such powerful adversaries.' This statement relates to a David and Goliath constellation between Snowden and intelligence agencies and are told from David's perspective and thus somewhat legitimise Snowden's disappearance. 
Published as: Lischka, J. A. (2016). Explicit terror prevention versus vague civil liberty: How the UK broadcasting news (de)legitimatise online mass surveillance since Edward Snowden's revelations. Information, Communication \& Society. doi:10.1080/1369118X.2016.1211721

Snowden's disappearance in Hong Kong is presented as mythopoetic story with open ending and suggests two interpretations. First, Snowden is an outlaw and a traitor, which is why the government wants to jail him. Second, the security agencies' and governments' power is globally threatening Snowden's wellbeing.

\section{Balance Surveillance against Privacy}

The need to balance security against surveillance is often a conclusion of the reports. A security correspondent summarises, 'Some will share his concern about this huge scale of surveillance. Others will say this is what is needed to prevent terrorist attacks and worry that his revelations might compromise that ability,' giving a reason why surveillance is needed. The Business secretary MP is quoted stating, 'you have got to have it $[\ldots]$ it has to be proportionate. You cannot have generalised snooping of individuals and you have to have some oversight, legal and political.' This criticism also relates to a moral evaluation of values such as accountability and democratic division of powers. Both statements lack a reason why a huge scale of surveillance should be avoided. Snowden's delegitimising argument that mass surveillance risks democracy is not explicitly taken on by editorial agents or other sources. Thus, the conclusions from the news reports are that current surveillance practices are going too far but are useful against terror, and that privacy should at most be balanced with online surveillance. 
Published as: Lischka, J. A. (2016). Explicit terror prevention versus vague civil liberty: How the UK broadcasting news (de)legitimatise online mass surveillance since Edward Snowden's revelations. Information, Communication \& Society. doi:10.1080/1369118X.2016.1211721

\section{David Miranda's Detention}

\section{Unlawfulness and Press Freedom}

The longer news reports of this case start from the journalists' perspective suggesting that the state made a mistake and conclude with implications for press freedom. The reports give voice to the persons concerned, David Miranda and Glenn Greenwald, who are upset about the events. The Chair of the Home Affairs Select Committee and the Liberal Democrat's spokesman critically comment the detention and reveal surprise ('raises more than my eyebrows'). The reports partly phonetically emphasize the detention duration 'nine hours' and contain emotional expressions such as 'extraordinary,' 'awful,' 'abused' or 'stretched' law, causing 'huge reactions' from a 'furious' public etc., indicating that the detention is dubious and unlawful. The discussion around the lawfulness of the detention relates to the authorisation delegitimation strategy.

In one case, the public views are presented by a Liberal Democrats spokesperson mentioning reactions on Twitter, 'They are furious that this has happened. They are extremely concerned at the idea that anybody can be detained on such slim evidence and such slim guidance on nine hours.' Thus, the legitimacy of the detention is strongly questioned through moral evaluation referring to the value of adequacy.

After the initial reports, the following ones take an overall journalists' standpoint beginning with the argument of threatening press freedom. The relating law, the Terrorism Act 2000, is discussed from the perspective of press freedom and thus its 
Published as: Lischka, J. A. (2016). Explicit terror prevention versus vague civil liberty: How the UK broadcasting news (de)legitimatise online mass surveillance since Edward Snowden's revelations. Information, Communication \& Society. doi:10.1080/1369118X.2016.1211721

authority is questioned. A reporter concludes, 'Before this detention, the talk around this particular law had focussed on civil liberties. Now the issue of journalistic freedom is part of the debate.' Two reports combine the detention and the destruction of the Guardian's hard drives adding a further press freedom example and recalls the necessity of a public debate about surveillance. The Guardian editor Alan Rusbridger states 'This is subject of high public importance [...] You cannot write about that if you have not got informed material and facts to deal with. [...] The British government has moved against the Guardian in a way that would be undoable in America.' This reference to US law delegitimises the actions of the UK government. He calls the destruction disproportionate and reflecting an 'old-fashioned attitude towards national security,' further delegitimising state control. Rusbridger calls the Terrorism Act 'bizarre' and lines out that 'That's what's disturbing people. That a measure that's supposed to be against terrorists is being used against journalists,' morally evaluating the values public debate and press freedom. Further, he emphasises that 'whole Europe is discussing this.' This reference to the European discussion provides legitimacy for the moral evaluation of the values of public interest and press freedom and stresses the need to discuss the issues publicly in the UK.

Overall, the detention and destruction of the Guardian's hard drives is story-like described by David Miranda and Alan Rusbridger, respectively, which is comparable to a David versus Goliath tale with powerful state authorities told from the weaker David's perspective and represents a mythopoesis strategy for delegitimation of the state's actions. 
Published as: Lischka, J. A. (2016). Explicit terror prevention versus vague civil liberty: How the UK broadcasting news (de)legitimatise online mass surveillance since Edward Snowden's revelations. Information, Communication \& Society. doi:10.1080/1369118X.2016.1211721

\section{Need for Security}

A reporter calls the destruction an 'act of vandalism' and concludes 'The Government will be hoping that the public is convinced by this argument of public safety rather than the Guardian's argument about press freedom...' An anchor starts with 'It's been described as the most serious threat to press freedom Britain has seen for ages. Alternatively, it was the action of the state, concerned for the welfare and security of its citizens. Desperate measures for desperate times.'

Whereas the $\mathrm{BBC}$ reports in detail and from supporting and opposing perspectives, news on other channels have not reported about the detention or only very briefly from one perspective, as on Channel 5 News. These shorter reports often begin from the state's perspective supporting its need for security, e.g., 'The Home Office and Scotland Yard have been threatened with legal action.' Further, the defending statement of the Home Secretary is often part of the reports, 'the government should protect the public if the police believe somebody has highly sensitive stolen information, which could help terrorists and lead to a loss of lives.' The detention, is justified by state, data, and public security and possible threats through terrorism and therefore follow a rationalisation and moral evaluation strategy. 
Published as: Lischka, J. A. (2016). Explicit terror prevention versus vague civil liberty: How the UK broadcasting news (de)legitimatise online mass surveillance since Edward Snowden's revelations. Information, Communication \& Society. doi:10.1080/1369118X.2016.1211721

\section{Snooping on Embassies and World Leaders}

\section{Breach of Trust}

The espionage revelations are related to Edward Snowden who is called a 'hero' by Julian Assange, whose statement is shown in one report on embassy snooping, because 'he has told the people of the world and the United States that there is mess, unlawful interception of their communication,' which assigns authority to Snowden. One report cites Snowden suggesting that spying was "more widespread than previously known with more than 35 world leaders targeted.' The outrage of Angela Merkel calling the snooping 'completely inacceptable' and 'a serious breach of trust' if it was true, the German people, the anger of the French diplomat, and President of the EU Parliament is touched on several times throughout the reports. The President of the European Parliament says he was 'deeply shocked' and 'angry' that the US spies on members of the EU. These emotional reactions relate to a moral evaluation concerning the value of political partnership and trust that were damaged. The US reaction supports this negative moral evaluation since 'The US is reviewing the way that we gather intelligence to properly balance the concerns of citizens and allies,' says a White House press secretary.

One report states that the German public reacts sensitively to surveillance due to the distinctive past of 'Stasi', the Ministry for State Security in former East Germany vastly spying on the population in order to fight any opposition, 'Memories here of surveillance in East Germany are fresh, and Germans were outraged about leaks coming 
Published as: Lischka, J. A. (2016). Explicit terror prevention versus vague civil liberty: How the UK broadcasting news (de)legitimatise online mass surveillance since Edward Snowden's revelations. Information, Communication \& Society. doi:10.1080/1369118X.2016.1211721

from Edward Snowden.' This example highlights a serious and threatening historical aspect of surveillance for a population. However, such an aspect is not taken up or discussed in relation to the current surveillance situation by the sources or journalists.

\section{Everybody Does It}

However, UK sources, be it politicians or foreign correspondents, do not express great surprise about the US spying activities. It is assumed that Merkel's anger is played. She "has to really climb the highest ladder of annoyance but are a lot of crocodile tears are being shared here,' because they suggest that everybody is spying on each other. This argumentation refers to a conformity authorization suggesting that spying is legitimate because 'everybody does it'. In addition, the intelligence services are described to do what they have to do 'to keep us in one piece,' which is an instrumental rationalisation for the purpose of security, relating to a moral evaluation of public security. The great extent of surveillance is touched stating 'that people all over the world may have their information hoovered up.' The final report on snooping concludes with stating that 'Most of the time we don't really know what they [intelligence] want to do or what they need to do. They [affected parties] need to all get over this.'

Whereas the reactions of German or French sources point at a moral difficulty of the spying activities by the US, the lack of outrage by the UK sources and the lack of a debate whether this had any consequences for the UK mute moral questions. 
Published as: Lischka, J. A. (2016). Explicit terror prevention versus vague civil liberty: How the UK broadcasting news (de)legitimatise online mass surveillance since Edward Snowden's revelations. Information, Communication \& Society. doi:10.1080/1369118X.2016.1211721

\section{Lee Rigby Report}

\section{Need for Security and Terrorism}

Broadcasts usually begin with statements from the Prime Minister requesting legislation enabling broader surveillance. The emergency of further legislation is emphasised in a statement of an MP, 'that people will die in this country who would have been safe if that [legislation] had been in place'. Facebook is described as 'safe-haven' for terrorists but the role of Internet companies should be 'to keep us safe' and 'to help a British counter-terrorist investigation.' The Prime Minister calls agencies 'silent heroes.'

\section{Privacy and Ineffectiveness of Online Surveillance}

Many broadcasts contrast the Prime Minister's request for a new legislation by adding alternative sources such as representatives of the Open Rights Group and other non-governmental organisations criticising the scope of online surveillance. A humanrights activist states, 'At times when they [security agencies] want to pull back on civil liberties, snoop on, they pull out terrorism as a trump card.' But if security agencies had access to any information this would lead to 'an absolute surveillance state at which point nobody has any kind of freedom to manoeuvre. You sacrifice the very thin you're tempting to defend. Terrorists win.' These statements use moral evaluations by indicating values of public debate, privacy, and civil liberty. A spokesperson of a counter-extremism organisation states that searching in online communication for terrorism search terms 
Published as: Lischka, J. A. (2016). Explicit terror prevention versus vague civil liberty: How the UK broadcasting news (de)legitimatise online mass surveillance since Edward Snowden's revelations. Information, Communication \& Society. doi:10.1080/1369118X.2016.1211721

'would not help you find a needle in a haystack. It would add more hay.' Similarly, intelligence agencies would go on a 'fishing expedition' in communication content. These arguments deny the instrumental rational legitimation of online surveillance's positive effect of security but suggests an ineffective utility.

These alternative sources and their critical statements on surveillance practices are unique in the broadcast surveillance debate. This explicit criticism was either absent in previous cases or at most indicated through statements of Snowden himself or partly through Alan Rusbridger regarding the destruction of the Guardian's hard drives.

\section{Charlie Hebdo Aftermath}

\section{Need for Security}

The data legislation called 'Snooper's Charter' is discussed in the background of the Paris attacks to give security agencies more power to look at online communications whereas security chiefs want to close gaps in their 'surveillance ability.' The Home Secretary warns that 'every day that passes, the capability of the people who keep us safe diminishes. As those more people in danger, crimes unpunished, innocent lives will be put at risk,' using the moral evaluation of values of national security. This argument is also used by a conservative MP stating that 'Public safety must come above everything else and that civil liberty must include not being bombed, shocked or beheaded.' The Home Secretary further assumes that 'communications data was used in the Paris attacks 
Published as: Lischka, J. A. (2016). Explicit terror prevention versus vague civil liberty: How the UK broadcasting news (de)legitimatise online mass surveillance since Edward Snowden's revelations. Information, Communication \& Society. doi:10.1080/1369118X.2016.1211721

to locate the suspects,' suggesting an effective utility of online surveillance which is related to instrumental rationalization.

\section{Regulate Power}

The Liberal Democrats oppose the data legislation they refer to as 'Snooper's Charter' and it is warned that too much power is given to security agencies. The draft data bill was rejected by a committee because it was 'to vague, too widely drawn, too much power in the hands of Home Secretary. They recommended that a new legislation was needed in a far more limited way and the government should provide more evidence and clarity about what they wanted to achieve.' This criticism also relates to a moral evaluation of values such as accountability and division of powers.

\section{Discussion and Conclusions}

The (de)legitimising strategies in the broadcast surveillance discourse cover the four types suggested by van Leeuwen and Wodak (1999). Legitimising arguments more strongly refer to instrumental rationality, i.e., the utility of surveillance for safety and fighting terrorism, which is related to a moral evaluation of public security (see Figure 1 for an overview). This legitimation strategy relates to the purpose of a state to protect its population as lined out by Foucault (2007). This issue of national security was also dominant in UK counter-terrorism policy documents (MacDonald \& Hunter, 2013). 
Published as: Lischka, J. A. (2016). Explicit terror prevention versus vague civil liberty: How the UK broadcasting news (de)legitimatise online mass surveillance since Edward Snowden's revelations. Information, Communication \& Society. doi:10.1080/1369118X.2016.1211721

Delegitimising arguments stress the moral evaluation of various values such as public interest, civil liberty, democracy, press freedom, or division of power that have to be protected or restored, and use mythopoesis telling David-and-Goliath type of stories from the perspective of David. Snowden's disappearing and David Miranda's detention are story-like told and thus may cause sympathy for the main characters. Some actors also deny a positive utility of surveillance to weaken the argument of instrumental rationality. Both sides also refer to authority legitimisations such as the law or conventionality and deny authority of or ascribe authority to Snowden, respectively. Similarly, Schulze (2015) shows that referring to the law is a dominant authorisation strategy in the German debate around the NSA surveillance scandal, which refers to the embassies and world leader snooping case in this study.

Perspectives on surveillance narrow down to the major theme terrorism prevention versus civil liberty and privacy, which is similar to Barnard-Wills' (2011) result of preventing criminality to limiting personal liberty. The repeated combination of instrumental rationality (terror prevention) and moral evaluation (public security) functions as a thought-terminating cliché for most delegitimising arguments.

Overall, there are no delegitimising arguments challenging online surveillance in general, but challenging arguments are related to surveillance practices. The most critical discourses on surveillance are held in reporting the David Miranda detention and the Lee Rigby report. The former is treated as infringing press freedom. The latter refers to 
Published as: Lischka, J. A. (2016). Explicit terror prevention versus vague civil liberty: How the UK broadcasting news (de)legitimatise online mass surveillance since Edward Snowden's revelations. Information, Communication \& Society. doi:10.1080/1369118X.2016.1211721

ineffective surveillance practices pointing out that broader online surveillance 'would not help you find a needle in a haystack. It would add more hay.' However, the delegitimising moral evaluation arguments are less explicitly than the legitimising rationalisation argument referring to terrorist threats. Civil liberties and privacy remain abstract, intangible terms. Except for obtaining bank records and reading emails, the detention of potentially innocent people in the David Miranda case, and destruction of corporate property in the case of the Guardian's hard drives, no threats to civil liberties of general people are mentioned. Explicit risks for democracy and society through changes in human behaviour as described by Sloan and Warner (2015), Acquisti et al. (2015) or Stoycheff (2016) are not part of the analysed broadcasts. Thus, threats to civil liberties and privacy appear negligible compared to terrorist threats within the British broadcast discourse on surveillance.

When comparing the rationalisation arguments of terrorist threats, the explicitness increases over time. Over the course of the cases, the expressions used for terroristic threats become more detailed. In the beginning, 'terrorist attacks' are rather factually mentioned (Snowden's unveiling), then terrorism 'could [...] lead to a loss of lives' (David Miranda detention), later 'people will die in this country' (Lee Rigby report), and finally 'being bombed, shocked or beheaded' (Charlie Hebdo aftermath) explicitly describes several ways leading to a loss of lives, which strengthens the instrumental rationality legitimation arguments. 
Published as: Lischka, J. A. (2016). Explicit terror prevention versus vague civil liberty: How the UK broadcasting news (de)legitimatise online mass surveillance since Edward Snowden's revelations. Information, Communication \& Society. doi:10.1080/1369118X.2016.1211721

Whereas the sources for legitimation are often governmental actors, sources of delegitimation arguments are more diverse and vary for each case. In three cases, i.e., Snowden's unveiling, the Lee Rigby report, and the aftermath of Charlie Hebdo, the focus is on elite actors who can mainly frame the surveillance interpretation as legitimate within broadcasts. The delegitimation strategies are mostly expressed by Snowden himself, journalists, governmental actors, and non-governmental organisations. Some (oppositional) politicians request a discussion about the proportionality of surveillance, which is a sign of a more moderate viewpoint of the state. However, the broadcast discourse tends to give governmental, pro-surveillance actors a voice by default. In contrast, it is harder for non-governmental actors to continuously interpret the broadcast discourse.

From a normative view, the broadcast news discourse touches challenging and justifying arguments, which is necessary to enable rational discussions in public. Thus, broadcast news cannot be described as government lapdog (McGarrity, 2011). A damage by Snowden's leaks as found in newspaper reporting by Branum and Charteris-Black (2015) is only a minor aspect in the broadcast debate. There are also no major differences in the surveillance discourse in broadcasts across TV or radio channels as in British newspapers caused by their editorial stance (Branum \& Charteris-Black, 2015). However, pro-surveillance arguments are expressed explicitly through terrorism having an immense negative threat for society compared to contra-surveillance arguments. Thus, the more 
Published as: Lischka, J. A. (2016). Explicit terror prevention versus vague civil liberty: How the UK broadcasting news (de)legitimatise online mass surveillance since Edward Snowden's revelations. Information, Communication \& Society. doi:10.1080/1369118X.2016.1211721

powerful arguments in combination with a default coverage may be received as more convincing by the audience than contra-surveillance arguments. In fact, what exactly is at stake when mass surveillance is broadened remains obscure in the broadcast discourse and thus is non-existent. Simone's (2009, p. 12) conclusion, 'If surveillance is security and security is liberty, then perhaps we would be better off living dangerously,' does not come clearly across in the UK broadcast surveillance debate.

To conclude, the surveillance discourse should be richer especially in order to give the audience a chance to understand the less concrete contra-surveillance arguments better. This underreporting is not caused by 'security and intelligence censorship' (Herfroy-Mischler, 2015, p. 244) but by not extensively enough including alternative sources than governmental actors and by the challenge to explain surveillance threats to democracy in a more tangible way to the public. Thus, the media should focus on how the surveillance debate can be 'broadened to enable a wider societal debate informed by the experiences of those subjected to targeted surveillance and associated state violence,' as proposed by Gürses et al. (2016, p. 577).

There are major limitations connected to this broadcast analysis. First, the sample is the best that could be accessed based on two extensive data bases. Since the observation periods are selected based on previously identified major events in surveillance coverage, major broadcast reports are part of the sample. However, it remains unclear how many broadcasts on surveillance not related to one of the cases are overlooked and are missed 
Published as: Lischka, J. A. (2016). Explicit terror prevention versus vague civil liberty: How the UK broadcasting news (de)legitimatise online mass surveillance since Edward Snowden's revelations. Information, Communication \& Society. doi:10.1080/1369118X.2016.1211721

out due to the keyword search and the way TV versus radio broadcasts are represented in the data bases used for searching. Surveillance matters may be discussed more broadly in other broadcasts not related to one of the cases. Hence, a conclusion that the general surveillance debate has become less diverse and has given pro-surveillance arguments more room since the Lee Rigby report cannot be drawn. Second, the analysis cannot evaluate whether the coverage of surveillance in British media is extensive relative to other topics. Also, in order to assess the British news media discourse on surveillance, an additional analysis of newspaper and online news outlets are necessary. Alternative news sources such as blogs can reveal a discourse produced by a wider circle of actors than journalists and editors. Finally, it would be interesting to assess how the audience actually perceives and understands the surveillance discourse in the media and whether chilling effects result for democratic discourses, as suggested by Stoycheff (2016).

\section{References}

Abu-Laban, Y., \& Bakan, A. B. (2012). After 9/11: Canada, the Israel/Palestine conflict, and the surveillance of public discourse. Canadian Journal of Law and Society, 27(3), 319-339.

Acquisti, A., Brandimarte, L., \& Loewenstein, G. (2015). Privacy and human behavior in the age of information. Science, 347(6221), 509-514.

doi:10.1126/science.aaa1465 
Published as: Lischka, J. A. (2016). Explicit terror prevention versus vague civil liberty: How the UK broadcasting news (de)legitimatise online mass surveillance since Edward Snowden's revelations. Information, Communication \& Society. doi:10.1080/1369118X.2016.1211721

Barnard-Wills, D. (2011). UK news media discourses of surveillance. The Sociological Quarterly, 52(4), 548-567. doi:10.1111/j.1533-8525.2011.01219.x

Branum, J., \& Charteris-Black, J. (2015). The Edward Snowden affair: A corpus study of the British press. Discourse \& Communication, 9(2), 199-220. doi:10.1177/1750481314568544

Brüggemann, M., Engesser, S., Büchel, F., Humprecht, E., \& Castro, L. (2014). Hallin and Mancini Revisited: Four Empirical Types of Western Media Systems. Journal of Communication, 64(6), 1037-1065. doi:10.1111/jcom.12127

Christensen, M., \& Jansson, A. (2015). Complicit surveillance, interveillance, and the question of cosmopolitanism: Toward a phenomenological understanding of mediatization. New Media \& Society, 17(9), 1473-1491. doi:10.1177/1461444814528678

Coll, S. (2014). Power, knowledge, and the subjects of privacy: Understanding privacy as the ally of surveillance. Information, Communication \& Society, 17(10), 12501263. doi:10.1080/1369118X.2014.918636

Committee of Ministers of the Council of Europe. (2005). Declaration on freedom of expression and information in the media in the context of the fight against terrorism. Retrieved from https://wcd.coe.int/ViewDoc.jsp?id=830679\&Site=CM

Fairclough, N. (1995). Media discourse. London, New York: E. Arnold. 
Published as: Lischka, J. A. (2016). Explicit terror prevention versus vague civil liberty: How the UK broadcasting news (de)legitimatise online mass surveillance since Edward Snowden's revelations. Information, Communication \& Society. doi:10.1080/1369118X.2016.1211721

Foucault, M. (2007). Security, territory, population: Lectures at the Collège de France, 1977-78. Basingstoke, New York: Palgrave Macmillan; République Française.

Gangadharan, S. P. (2015). The downside of digital inclusion: Expectations and experiences of privacy and surveillance among marginal Internet users. New Media \& Society. doi:10.1177/1461444815614053

Greenberg, J., \& Hier, S. (2009). CCTV surveillance and the poverty of media discourse: A content analysis of Canadian newspaper coverage. Canadian Journal of Communication, 34(3), 461-486.

Guardian US. (2013). NSA whistleblower Edward Snowden: 'I don't want to live in a society that does these sort of things' - video. Retrieved from http://www.theguardian.com/world/video/2013/jun/09/nsa-whistleblower-edwardsnowden-interview-video

Gürses, S., Kundnani, A., \& van Hoboken, J. (2016). Crypto and empire: The contradictions of counter-surveillance advocacy. Media, Culture \& Society, 38(4), 576-590. doi:10.1177/0163443716643006

Habermas, J. (1989). The structural transformation of the public sphere: An inquiry into a category of bourgeois society. Cambridge: Polity Press.

Herfroy-Mischler, A. (2015). Silencing the agenda?: Journalism practices and intelligence events: A case study. Media, War \& Conflict, 8(2), 244-263. doi:10.1177/1750635215584285 
Published as: Lischka, J. A. (2016). Explicit terror prevention versus vague civil liberty: How the UK broadcasting news (de)legitimatise online mass surveillance since Edward Snowden's revelations. Information, Communication \& Society. doi:10.1080/1369118X.2016.1211721

Lyon, D. (1998). The world wide web of surveillance: The internet and off-world power-flows. Information, Communication \& Society, 1(1), 91-105. doi:10.1080/13691189809358955

Lyon, D. (2002). Everyday surveillance: Personal data and social classifications. Information, Communication \& Society, 5(2), 242-257. doi:10.1080/13691180210130806

Lyon, D. (2004). Globalizing surveillance: Comparative and sociological perspectives. International Sociology, 19(2), 135-149. doi:10.1177/0268580904042897

MacDonald, M. N., \& Hunter, D. (2013). Security, population and governmentality: UK counter-terrorism discourse (2007-2011). Critical Approaches to Discourse Analysis Across Disciplines, 7(1), 123-140.

MacDonald, M. N., Hunter, D., \& O'Regan, J. P. (2013). Citizenship, community, and counter-terrorism: UK security discourse, 2001-2011. Journal of Language and Politics, 12(3), 445-473. doi:10.1075/jlp.12.3.07mac

McGarrity, N. (2011). Fourth estate or government lapdog? The role of the Australian media in the counter-terrorism context. Continuum: Journal of Media \& Cultural Studies, 25(2), 273-283. doi:10.1080/10304312.2011.553946

McQuail, D. (2005). McQuail's mass communication theory (5th ed.). London: Sage. 
Published as: Lischka, J. A. (2016). Explicit terror prevention versus vague civil liberty: How the UK broadcasting news (de)legitimatise online mass surveillance since Edward Snowden's revelations. Information, Communication \& Society. doi:10.1080/1369118X.2016.1211721

Picard, R. G. (2015). The humanisation of media?: Social media and the reformation of communication. Communication Research and Practice, 1(1), 32-41. doi:10.1080/22041451.2015.1042421

Richardson, J. E. (2007). Analysing newspapers: An approach from critical discourse analysis. Basingstoke [England], New York: Palgrave Macmillan.

Schulze, M. (2015). Patterns of surveillance legitimization: The German discourse on the NSA scandal. Surveillance \& Society, 13(2), 197-217.

Simone, M. A. (2009). Give me liberty and give me surveillance: A case study of the US Government's discourse of surveillance. Critical Discourse Studies, 6(1), 1-14. doi:10.1080/17405900802559977

Sloan, R. H., \& Warner, R. (2015). The harm in merely knowing: Privacy, complicity, surveillance, and the self. Journal of Internet Law, 19(1), 3-14.

Stoycheff, E. (2016). Under surveillance: Examining Facebooks spiral of silence effects in the wake of NSA Internet monitoring. Journalism \& Mass Communication Quarterly, 93(2), 296-311. doi:10.1177/1077699016630255

Sup Park, C. (2014). Media cross-ownership and threat to diversity: A discourse analysis of news coverage on the permission for cross-ownership between broadcasters and newspapers in South Korea. International Journal of Media \& Cultural Politics, 10(1), 43-64. doi:10.1386/macp.10.1.43_1 
Published as: Lischka, J. A. (2016). Explicit terror prevention versus vague civil liberty: How the UK broadcasting news (de)legitimatise online mass surveillance since Edward Snowden's revelations. Information, Communication \& Society. doi:10.1080/1369118X.2016.1211721

van Dijk, T. A. (2006). Discourse and manipulation. Discourse \& Society, 17(3), 359383. doi:10.1177/0957926506060250

van Leeuwen, T. (2007). Legitimation in discourse and communication. Discourse \& Communication, 1(1), 91-112. doi:10.1177/1750481307071986

van Leeuwen, T., \& Wodak, R. (1999). Legitimizing immigration control: A discoursehistorical analysis. Discourse Studies, 1(1), 83-118.

doi:10.1177/1461445699001001005

Wiegand, V. (2015, July). The representation of surveillance discourses in UK broadsheets: A corpus linguistic approach. Lancaster University. Corpus Linguistics 2015, Lancaster. 
Published as: Lischka, J. A. (2016). Explicit terror prevention versus vague civil liberty: How the UK broadcasting news (de)legitimatise online mass surveillance since Edward Snowden's revelations. Information, Communication \& Society. doi:10.1080/1369118X.2016.1211721

Table 1: Search terms and number of broadcasts per case

\begin{tabular}{|c|c|c|c|c|c|}
\hline & (1) Edward & (2) David & (3) Embassies & (4) Lee & (5) Charlie \\
\hline & Snowden's & Miranda & and world & Rigby & Hebdo \\
\hline & unveiling & & leader & report & aftermath \\
\hline & & & snooping & & \\
\hline \multirow[t]{4}{*}{ Timeframe } & $09 / 06 / 13-$ & $18 / 08 / 13-$ & $29 / 06 / 13-$ & $15 / 11 / 14$ & $07 / 01 / 15-$ \\
\hline & $16 / 06 / 13$ & $15 / 09 / 13$ & $27 / 07 / 13$ and & - & $04 / 02 / 15$ \\
\hline & & & $11 / 10 / 13-$ & $13 / 12 / 14$ & \\
\hline & & & 08/11/13 & & \\
\hline \multirow[t]{4}{*}{ Search terms } & 'Edward & 'David & 'European & 'Lee & 'Charlie \\
\hline & Snowden' & Miranda' & Commission' & Rigby' & Hebdo' OR \\
\hline & & & OR 'Merkel's & AND & Paris AND \\
\hline & & & phone' & Facebook & surveillance \\
\hline Number of & 4 & 12 & $2(2)$ & 8 & $1(1)$ \\
\hline broadcasts & (4) & (8) & (European & (7) & \\
\hline \multicolumn{2}{|l|}{ (programmes } & & Commission); & & \\
\hline \multirow[t]{3}{*}{ obtained) } & & & $11(11)$ & & \\
\hline & & & (Merkel's & & \\
\hline & & & phone) & & \\
\hline
\end{tabular}

Source: compiled by the author 
Published as: Lischka, J. A. (2016). Explicit terror prevention versus vague civil liberty: How the UK broadcasting news (de)legitimatise online mass surveillance since Edward Snowden's revelations. Information, Communication \& Society. doi:10.1080/1369118X.2016.1211721

Delegitimising online mass surveillance

Legitimising online mass surveillance

(1) Snowden's unveiling (Jun 2013)

Moral evaluation: Public interest, privacy

Instrumental rationality: Terror prevention

Authority: Snowden, Surveillance is unlawful \& Moral evaluation: Public security

Authority: Surveillance is lawful, Conformity to offline surveillance; De-authority: 'Baseless accusations'

Mythopoesis: Snowden's disappearance

Moral evaluation: Balance surveillance against privacy

(2) David Miranda's detention (Aug/Sept 2013)

Moral evaluation: Press freedom, public debate

Instrumental rationality: Terror prevention

Authority: Detention is unlawful

Mythopoesis: Guardian's hard drive destruction

(3) Snooping on embassies and world leaders (Jun/Jul and Oct/Nov 2013)

Moral evaluation: 'State' privacy, trust

Authority: Conformity 'Everyone does it'

Authority: Snowden, Surveillance is unlawful \& Moral evaluation: Public security

(4) Lee Rigby report (Nov/Dec 2014)

Moral evaluation: Public debate, privacy, civil liberty

Deny of instrumental rationality: Ineffective terror

prevention ('Adds more hay'; 'Play terrorism as trump card')

(5) Charlie Hebdo aftermath (Jan/Feb 2015)

Instrumental rationality: Terror prevention \& Moral evaluation: Public security

Moral evaluation: Regulate power of security agencies

Figure 1 (De)Legitimation arguments for online surveillance

Source: compiled by the author

Note: The course of the debate is indicated with arrows. Concluding (de)legitimation arguments are framed and key arguments printed in bold for each case. 